\title{
Enhanced soil aggregate stability limits colloidal phosphorus loss potentials in agricultural systems
}

Li, Fayong; Liang, Xinqiang; Li, Hua; Jin, Yingbin; Jin, Junwei; He, Miaomiao; Klumpp, Erwin; Bol, Roland

\section{Environmental Sciences Europe}

DOI:

$10.1186 / \mathrm{s} 12302-020-0299-5$

Published: 10/02/2020

Publisher's PDF, also known as Version of record

Cyswllt i'r cyhoeddiad / Link to publication

Dyfyniad o'r fersiwn a gyhoeddwyd / Citation for published version (APA):

Li, F., Liang, X., Li, H., Jin, Y., Jin, J., He, M., Klumpp, E., \& Bol, R. (2020). Enhanced soil aggregate stability limits colloidal phosphorus loss potentials in agricultural systems. Environmental Sciences Europe, 32(1), [17]. https://doi.org/10.1186/s12302-020-0299-5

\footnotetext{
Hawliau Cyffredinol / General rights

Copyright and moral rights for the publications made accessible in the public portal are retained by the authors and/or other copyright owners and it is a condition of accessing publications that users recognise and abide by the legal requirements associated with these rights.

- Users may download and print one copy of any publication from the public portal for the purpose of private study or research.

- You may not further distribute the material or use it for any profit-making activity or commercial gain

- You may freely distribute the URL identifying the publication in the public portal?
}

Take down policy

If you believe that this document breaches copyright please contact us providing details, and we will remove access to the work immediately and investigate your claim. 


\title{
Enhanced soil aggregate stability limits colloidal phosphorus loss potentials in agricultural systems
}

\author{
Fayong Li ${ }^{1,2}$, Xinqiang Liang ${ }^{1 *} \mathbb{D}, \mathrm{Hua} \mathrm{Li}^{3}$, Yingbin $\mathrm{Jin}^{1}$, Junwei Jin ${ }^{1}$, Miaomiao He${ }^{4}$, Erwin Klumpp ${ }^{5}$ \\ and Roland $\mathrm{Bo}^{5,6}$
}

\begin{abstract}
Background: Colloid-facilitated phosphorus (P) transport is recognized as an important pathway for the loss of soil $P$ in agricultural systems; however, information regarding soil aggregate-associated colloidal $P\left(P_{\text {coll }}\right)$ is lacking. To elucidate the effects of aggregate size on the potential loss of $\mathrm{P}_{\text {coll }}$ in agricultural systems, soils $(0-20 \mathrm{~cm}$ depth) from six land-use types were sampled in the Zhejiang Province in the Yangtze River Delta region, China. The aggregate size fractions ( $2-8 \mathrm{~mm}, 0.26-2 \mathrm{~mm}, 0.053-0.26 \mathrm{~mm}$ and $<0.053 \mathrm{~mm}$ ) were separated using the wet sieving method. Colloidal $P$ and other soil parameters in aggregates were analyzed.
\end{abstract}

Results: Our study demonstrated that 0.26-2 mm small macroaggregates had the highest total P (TP) content. In acidic soils, the highest $P_{\text {coll }}$ content was observed in the 0.26 - to 2 - $\mathrm{mm}$-sized aggregates, while the lowest was reported in the $<0.053 \mathrm{~mm}$ (silt + clay)-sized particles, the opposite of that revealed in alkaline and neutral soils. Paddy soils contained less $P_{\text {coll }}$ than other land-use types. The proportion of $P_{\text {coll }}$ in total dissolved $P$ (TDP) was dominated by $<0.053 \mathrm{~mm}$ (silt + clay)-sized particles. Aggregate size strongly influenced the loss potential of $P_{\text {coll }}$ in paddy soils, where $\mathrm{P}_{\text {coll }}$ contributed up to 83\% TDP in the silt + clay-sized particles. The $\mathrm{P}_{\text {coll }}$ content was positively correlated with TP, Al, Fe, and the mean weight diameter. Aggregate-associated total carbon (TC), total nitrogen (TN), C/P, and C/N had significant negative effects on the contribution of $\mathrm{P}_{\text {coll }}$ to potential soil $\mathrm{P}$ loss. The $\mathrm{P}_{\text {coll }}$ content of the aggregates was controlled by the aggregate-associated TP and Al content, as well as the soil pH value. The potential loss of $\mathrm{P}_{\text {coll }}$ from aggregates was controlled by its organic matter content.

Conclusion: We concluded that management practices that increase soil aggregate stability or its organic carbon content will limit $P_{\text {coll }}$ loss in agricultural systems.

Keywords: Soil aggregate, Colloidal phosphorus, pH, Geometric mean diameter, Loss of phosphorus

\section{Background}

The loss of phosphorus (P) from agricultural soils has been identified as one of the main causes of eutrophication of lakes in the lower reaches of the Yangtze River in southern China [1]. Statistics have shown that major lakes and reservoirs in this area were eutrophic and

\footnotetext{
*Correspondence: liang410@zju.edu.cn

${ }^{1}$ College of Environmental and Resources Sciences, Zhejiang University, Hangzhou 310058, China

Full list of author information is available at the end of the article
}

mesotrophic [2-4], and the Yangtze River Delta region accounted for $17 \%$ of the $10 \mathrm{Tg}$ annual increase in soil $\mathrm{P}$ around the world [2]. In soil, colloidal $\mathrm{P}\left(\mathrm{P}_{\text {coll }}\right)$ is the $\mathrm{P}$ fraction bound to colloids [5]. Colloidal particles are highly mobile and are effective adsorbents of organic and inorganic contaminants and nutrient elements, such as $\mathrm{P}$, owing to the high specific surface area and charge density $[6,7]$. Colloid-facilitated P transport is an important pathway for the migration of $P$ into water bodies $[5,8,9]$. One study has reported that more than $75 \%$ of $\mathrm{P}$ in cultivated soil solution is combined with fine particles smaller 
than $240 \mathrm{~nm}$ [10]; similarly, $40-58 \%$ of molybdate-reactive $P$, with a size less than $450 \mathrm{~nm}$ in the water extract of grassland soil, demonstrates fine-grained $\mathrm{P}$ with a size of 25-450 nm [9]. Other studies have suggested that $P_{\text {coll }}$ reached up to $50 \%$ of total $\mathrm{P}$ (TP) in surface runoff, rivers, and lakes [11], which may lead to environmental risks.

Soil aggregate stability plays a key role in controlling the erosion processes and the loss of soil nutrients [1214]. Water-dispersible colloids in the soil adhere to soil aggregates, forming a stable system [15]. Colloids either can bind to soil aggregates, or be physically strained from water flowing through pores between aggregates $[16,17]$. Some scholars determined the colloid content in 1-2 mm aggregates in 39 soils and revealed a significant positive correlation between the water-dispersible colloid content and clay content in soil aggregates [18]. Furthermore, they reported that water-dispersible colloid content was a function of total organic $\mathrm{C}$ and total clay. Other scholars modeled the release characteristics of colloids from soil aggregates, the attachment and detachment processes at the air-water interface, and flocculation and straining from interstitial water [19]. The release of colloids from aggregates may result in the disintegration of aggregates [20]. However, soil aggregation mainly depends on the availability of active mineral surfaces and the dispersion/ flocculation behaviors of the colloidal components [21]. Meanwhile, the degree of clay colloid dispersion can be reduced by increasing the aggregate stability $[18,22,23]$. Therefore, the stability of soil aggregates directly affects the migration of soil colloids.

The retention of $\mathrm{P}$ in soil aggregates depends on the aggregate sizes and chemical properties [24, 25]. Notably, $\mathrm{P}$ has a relatively closed cycle, with most of the mineralized and dissolved P from microaggregates adsorbed onto unaggregated clay-sized particles $(<53 \mu \mathrm{m})$ or utilized by plants [26]. Reportedly, some studies have shown that the soil aggregate stability and size affect the soil $\mathrm{P}$ distribution [27-29]. Higher percentages of both waterextractable and Mehlich III-extractable P were observed in both the $0.50-0.25$ and $0.25-0.125 \mathrm{~mm}$ aggregate fractions [30]. In contrast, reports have suggested that TP is the highest in small soil aggregates [31], or the TP content is uniform in soil aggregates of all sizes, whereas available $\mathrm{P}$ is higher in small soil aggregates [32]. Soil aggregation could reduce the loss of organic $\mathrm{P}$ in aggregates and increase the adsorption of inorganic $\mathrm{P}$ by silt and clay particles [26]. Meanwhile, the P forms in soil aggregates may vary with different particle sizes and land-use types [24, 33]. For example, a study has indicated that aluminum oxide bond $\mathrm{P}(\mathrm{Al}-\mathrm{P})$ is mainly dominated by soil aggregates $<1 \mathrm{~mm}$; those of $2-8 \mathrm{~mm}$ were mainly iron oxide bond $\mathrm{P}(\mathrm{Fe}-\mathrm{P})$ and calcium oxide bond $\mathrm{P}(\mathrm{Ca}-\mathrm{P})$ [34]. Other investigators have claimed that the labile $\mathrm{P}$ in macroaggregates was higher under native land-use than other land uses, further confirming that soils under native use contained more Ca-bound $\mathrm{P}$ in macroaggregates than the disturbed soils [35]. These studies provide the first basis for the better understanding the relationship between soil aggregates and $\mathrm{P}$.

To date, information on the $\mathrm{P}_{\text {coll }}$ content and its loss potential from aggregates remains limited. The impact of the aggregation process on the $\mathrm{P}_{\text {coll }}$ content in soils remains unclear. Moreover, the composition and structure of soil aggregates vary under different land-use management [36, 37]. There are fewer large-sized aggregates present in rice soil than dryland due to long-term flooding and anaerobic conditions that cause the macroaggregates to be dispersed [36, 38]. In addition, alternation between dry and wet conditions generally destroys macroaggregates and enhances the decomposition of organic carbon in paddy soils [39]. Therefore, we suspected that the content of $\mathrm{P}_{\text {coll }}$ in the macroaggregates of paddy soils was less than dryland soils, mainly existing in microaggregates and small particles, with a higher loss potential.

This study mainly aimed to understand the effect of soil aggregate stability on soil $\mathrm{P}_{\text {coll }}$ content and its loss potential, and to assess the core environmental factors affecting $\mathrm{P}_{\text {coll }}$ in soil aggregates. Hence, we collected soil samples from 15 sites and 6 land-use types in the Yangtze River Delta region, Zhejiang Province for aggregates and $\mathrm{P}_{\text {coll }}$ analysis. Firstly, we isolated the different-sized aggregates in the soil samples. Secondly, we determined the $\mathrm{P}_{\text {coll }}$, total carbon (TC), TP, total nitrogen $(\mathrm{TN}), \mathrm{Al}$, $\mathrm{Fe}$, and $\mathrm{Ca}$ content in each aggregate size fractions. We hypothesized that (1) larger sized aggregates have higher TP and $\mathrm{P}_{\text {coll }}$ content; (2) aggregates with a higher TC content have lower loss potential of $\mathrm{P}_{\text {coll }}$, and (3) land-use management with single rice has a higher loss potential of $\mathrm{P}_{\text {coll }}$.

\section{Materials and methods \\ Soil sampling and preparation}

In total, soils with different land-use types (Fig. 1) were collected from 15 sites, which were almost evenly distributed in the Zhejiang Province (an area of 1,055,000 $\mathrm{km}^{2}$ ). Information on specific sampling points is presented in Table 1 . The 15 sampling points covered six land-use types including orchards, single cropping rice, doublecropping rice, rice-rape rotation, rice-wheat rotation, and vegetables, generally established in the past 5 years.

Soil samples of $0-20 \mathrm{~cm}$ were collected from typical fields (long-term farmland with conventional fertilization by local farmers) in May 2018 during the second season of rotation systems and in other land-use types. Two samples, with three replicates, were obtained at intervals of $1000 \mathrm{~m}$ at each site with the same land-use type. 


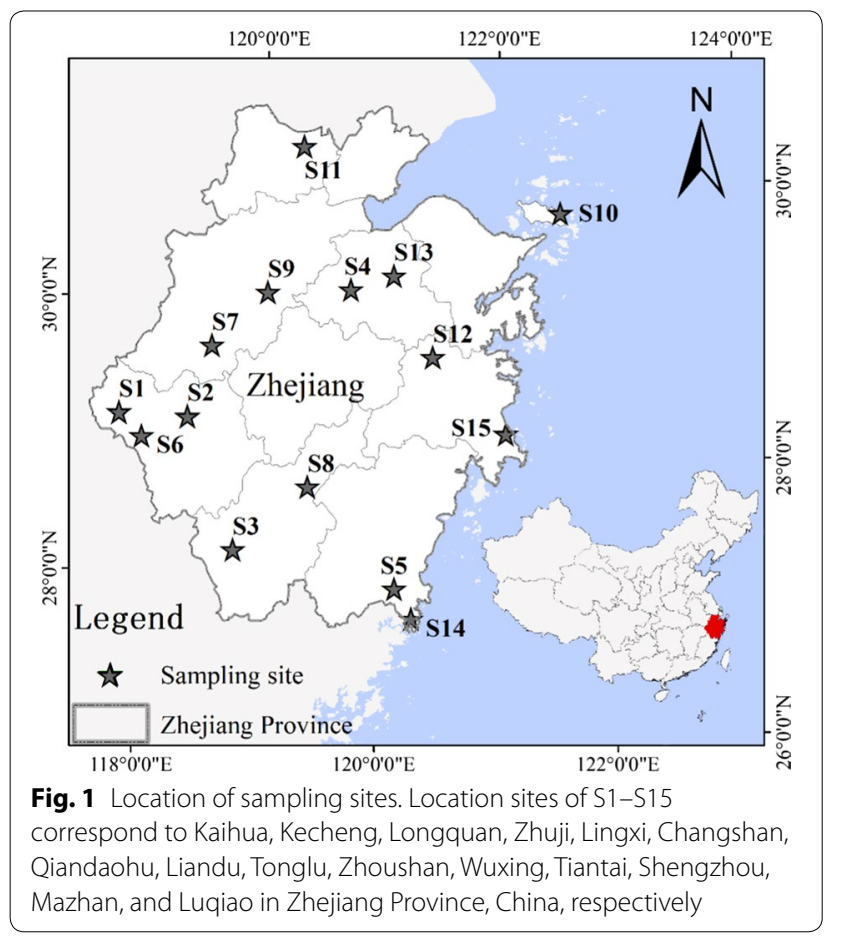

Next, the replicates were brought back to the laboratory and mixed. Then, the mixed soil samples from each site were divided into four equal parts by the diagonal quartering method and maintained for a follow-up test. All samples were air-dried and separated into two parts: one was finely milled and sieved through a 2-mm mesh to determine basic physical and chemical properties, and the other was carefully broken into small pieces manually and passed through an 8-mm sieve for aggregate separation and $\mathrm{P}_{\text {coll }}$ determination.

\section{Aggregate separation and determination}

Aggregate size distribution was determined for each soil sample using a modified wet sieving method [40]. Briefly, $50 \mathrm{~g}$ of unground soil, passed through an 8-mm sieve, was carefully placed above a nest of three sieves $(2 \mathrm{~mm}, 0.26 \mathrm{~mm}$, and $0.053 \mathrm{~mm})$. Then, the sieves were submerged for $20 \mathrm{~min}$ in $2.5 \mathrm{~L}$ deionized water at room temperature and oscillated 300 times for 10 min with a 30-mm amplitude to separate aggregate fractions. Thus, four aggregate fractions were obtained on each sieve: large macroaggregates $(2-8 \mathrm{~mm})$, small macroaggregates $(0.26-2 \mathrm{~mm})$, microaggregates $(0.053-0.26 \mathrm{~mm})$, and (silt + clay)-sized particles $(<0.053 \mathrm{~mm})$ [41]. Aggregates of each size were carefully removed from the sieve and placed into a beaker. The water used for wet sieving was left to rest for $48 \mathrm{~h}$, silt and clay particles were collected, and the supernatant was used to determine total dissolved P (TDP), truly soluble P (TSP), and $\mathrm{P}_{\text {coll }}$ content.
All aggregates were oven-dried at $65^{\circ} \mathrm{C}$ for $48 \mathrm{~h}$, weighed, and placed in a zip lock bag. To obtain water-stable aggregates, the sediment concentration was subtracted from that obtained by wet sieving as sand was not considered a component of water-dispersible aggregates [40]. The sand content was determined by the following process: $5 \mathrm{~g}$ of the dry aggregates obtained above were weighed, dispersed into $30 \mathrm{~mL} 5 \mathrm{~g} \mathrm{~L}^{-1}$ hexametaphosphate solution, placed into an ultrasonic cleaner, and dispersed for $30 \mathrm{~min}$. The suspension was then poured through a nest of sieves. The residue left on the $0.053-\mathrm{mm}$ sieve represented the sand content of each sized aggregate. After collection, sand was dried at $65^{\circ} \mathrm{C}$ and weighed.

Soil $\mathrm{pH}$ was determined with a glass electrode $\mathrm{pH}$ meter (PHS-3C, Shanghai) using a soil-to-water ratio of 1:5. Soil cation exchange capacity was measured with ammonium acetate $\left(12.5 \mathrm{~mL} 1 \mathrm{M} \mathrm{NH}_{4} \mathrm{OAc}, 2.5\right.$ g soil) [42]. Soil and aggregate-associated TP was determined by $\mathrm{H}_{2} \mathrm{SO}_{4}-\mathrm{HClO}_{4}$ digestion and evaluated using the molybdenum-blue colorimetric method [43]. Soil particle size distribution was determined by the hydrometric method according to an international soil texture classification standard. Soil- and aggregate-associated TC and TN were determined using an elemental analyzer (dry combustion with Vario MAX CNS, Elementar, Germany). Soil- and aggregate-associated $\mathrm{Al}, \mathrm{Fe}$, and $\mathrm{Ca}$ were determined by inductively coupled plasma mass spectrometry (ICP-MS) after digestion with $5 \mathrm{~mL} \mathrm{HNO}_{3}(16 \mathrm{M}), 1 \mathrm{~mL} \mathrm{HClO}_{4}$ $(12.4 \mathrm{M})$, and $1 \mathrm{~mL} \mathrm{HF}(23 \mathrm{M})$ for $12 \mathrm{~h}$. All reagents were acquired from Sinopharm Chemical Reagent Co., Ltd.

Colloidal P was determined as described by Ilg [44]. Briefly, $10 \mathrm{~g}$ of unground soil was placed into a $250-\mathrm{mL}$ flask, $80 \mathrm{~mL}$ deionized water was added. The sample was shaken at $160 \mathrm{rpm}$ and $25^{\circ} \mathrm{C}$ for $24 \mathrm{~h}$. The supernatant was pre-centrifuged at $3000 \mathrm{~g}$ for $10 \mathrm{~min}$ to remove coarse particles. After pre-centrifugation, the supernatant was filtered with a $1-\mu \mathrm{m}$ microporous membrane, $5 \mathrm{~mL}$ of the primary filtrate was discarded, and the total filtrate was collected (sample I). This suspension included the colloidal and dissolved components. The filtrate was ultracentrifuged at $300,000 \mathrm{~g}$ for $2 \mathrm{~h}$ to remove colloids (Optima TL, Beckman, USA; Sample II), and the residue at the bottom of the ultracentrifuge tube demonstrated the water-dispersible colloids. The TDP in Sample I and TSP in Sample II, in the solution, were determined after digestion with acidic potassium persulfate. The concentration of $\mathrm{P}_{\text {coll }}$ indicated the difference between TDP in Sample I and TSP in Sample II. Previous studies have shown that soil $\mathrm{P}$ through leaching and surface runoff was usually in the soluble form, that can pass through the $0.45-1 \mu \mathrm{m}$ filter $[45,46]$; therefore, in the present study, TDP including $\mathrm{P}_{\text {coll }}$ and TSP in aggregates was defined as the potential loss $\mathrm{P}$, and the $\mathrm{P}_{\text {coll }}$ in TDP was defined as 


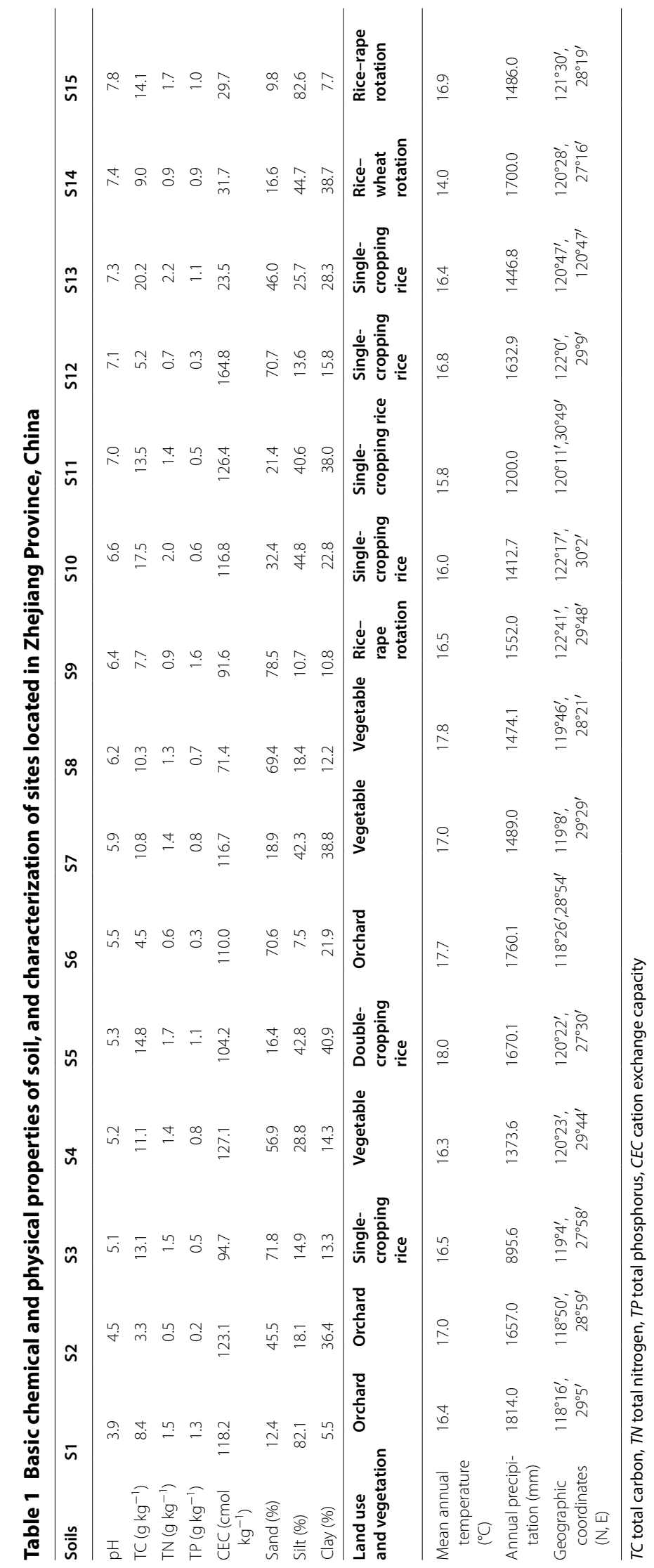


$\mathrm{P}_{\text {coll }}$ loss potential. TDP in the supernatant after $10 \mathrm{~min}$ wet sieving was considered as easy loss P.

\section{Calculation of water-stable aggregate (WSA) size fractions} The proportion of WSA in each size fraction was obtained from Eqs. (1) and (2), as described by AlvaroFuentes [47]:

$$
\begin{aligned}
& \mathrm{WSA}_{i}=\frac{\mathrm{DSA}_{i}-\mathrm{Sand}_{i}}{\text { Total }_{\text {Soil }}-\sum_{i=1}^{n} \operatorname{Sand}_{i}}, \\
& (\text { silt }+ \text { clay }) \text { sized fraction }=1-\sum_{i=1}^{n} \mathrm{WSA}_{i},
\end{aligned}
$$

where $i$ is the $i$ th size fraction $(2-8,0.25-2$, and $0.053-$ $0.25 \mathrm{~mm}$ ); dry soil aggregate $\left(\mathrm{DSA}_{i}\right)$ is the oven-dried mass of total, non-dispersed aggregates collected on each sieve; sand is the oven-dried mass of sand collected after dispersal in the hexametaphosphate solution on the $0.053 \mathrm{~mm}$ sieve; Total $_{\text {Soil }}$ is the oven-dried mass of soil $(50 \mathrm{~g})$ for aggregate separation.

\section{Calculation of mean weight diameter (MWD) and geometric mean diameter (GMD)}

The MWD and GMD of the aggregates were obtained by Eqs. (3) and (4) [48]:

$$
\begin{aligned}
& \mathrm{MWD}=\sum_{i=1}^{n} d_{i} \times \mathrm{WSA}_{i}, \\
& \mathrm{GMD}=\operatorname{EXP}\left[\frac{\sum_{i=1}^{n} \mathrm{WSA}_{i} \log d_{i}}{\sum_{i=1}^{n} \mathrm{WSA}_{i}}\right],
\end{aligned}
$$

where $i$ is the $i$ th size fraction $(2-8,0.26-2,0.053-0.26$, and $<0.053 \mathrm{~mm}$ ) and $d$ is the mean diameter of each size $(0.053-2 \mathrm{~mm})$. WSA $_{i}$ include $2-8,0.26-2,0.053-0.25$, and $<0.053 \mathrm{~mm}$ WSA and (silt + clay)-sized fractions.

\section{Contribution of aggregate-associated $\mathrm{P}_{\text {coll }}$ to TDP}

The contribution rate $(\mathrm{CR})$ was used to explore the impact of aggregate sizes on the $\mathrm{P}_{\text {coll }}$ loss potential, calculated using Eq. (5):

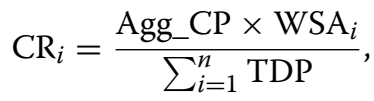

where Agg_CP is the concentration of aggregate-associated $\mathrm{P}_{\text {coll }}\left(\mathrm{mg} \mathrm{kg}^{-1}\right)$, TDP is the concentration of total dissolved $\mathrm{P}\left(\mathrm{mg} \mathrm{kg}^{-1}\right)$, and $\mathrm{i}$ is the ith size fraction (2-8, $0.26-2,0.053-0.26$, and $<0.053 \mathrm{~mm}$ ).

\section{Statistical analysis}

Microsoft Excel 2016 and Origin 8.0 were used for data processing and cartography. Data were statistically analyzed using SPSS Statistics 22.0 (SPSS Inc. Chicago, USA) software. One-way ANOVA was performed using two samples from each site to examine differences of different variables as presented in Additional file 1: Tables S1, S2, and Figures S1, S2 and Table 3. Pearson correlation analysis was used to identify the relationship between aggregate-associated $\mathrm{P}_{\text {coll }}$ and other soil parameters. Stepwise linear regression was performed to evaluate the relationships between $\mathrm{P}$ indicators (content and loss potential of $\left.\mathrm{P}_{\text {coll }}\right)$ and soil variables $(\mathrm{pH}, \mathrm{TP}, \mathrm{TC}, \mathrm{TN}, \mathrm{C} / \mathrm{N}, \mathrm{Fe}, \mathrm{Al}, \mathrm{Ca}$, MWD, and GMD).

\section{Results}

\section{Soil and aggregate characteristics}

Within the 15 soils collected, ten were acidic soils, two were neutral soils, and three were alkaline soils (Table 1). There were six land-use types: orchard, single cropping rice, rice-rape rotation, vegetable, double-cropping rice, and rice-wheat rotation. The $\mathrm{TC}$ of the soils ranged from 3.32 to $20.19 \mathrm{~g} \mathrm{~kg}^{-1}$; TN ranged between 0.53 and $2.17 \mathrm{~g} \mathrm{~kg}^{-1}$. TP varied from 0.23 to $1.64 \mathrm{~g} \mathrm{~kg}^{-1}$. Soil $\mathrm{pH}$ values ranged between 3.95 and 7.83 (Table 1).

The DSA and WSA of larger macroaggregates (2-8 $\mathrm{mm}$ ) generally increased with increasing $\mathrm{pH}$ values (Additional file 1: Figures S1 and S2, Table S2). Moreover, fractions of DSA and WSA $(2-8 \mathrm{~mm})$ in acidic soils ranged from 18.7 to $33.4 \%$ and from 10.5 to $47.1 \%$, respectively. Conversely, fractions of DSA and WSA in alkaline soils ranged from 39.7 to $56.1 \%$ and from 38.1 to $55.6 \%$, respectively. In contrast, size fractions of $<0.053 \mathrm{~mm}$ particles gradually decreased with increasing soil $\mathrm{pH}$ values, while the average contents of $<0.053 \mathrm{~mm}$ particles in acidic soils were 18.8 and $17.8 \%$, compared with only $11.2 \%$ and $14.7 \%$ in alkaline soils, respectively.

The MWDs of acidic soils $(\mathrm{pH}<5.5)$ were significantly smaller than those of alkaline soils $(P<0.05)$. The average MWD of acidic soils was $0.78 \mathrm{~mm}$ (Additional file 1: Figure S2), while that of neutral and alkaline soils was $1.36 \mathrm{~mm}$. However, little difference in GMDs was observed between acidic $(0.85 \mathrm{~mm})$, and alkaline soils (0.91 mm).

\section{Total and colloidal phosphorus content}

Generally, the $0.26-2 \mathrm{~mm}$ aggregate fraction demonstrated the highest TP content, which accounted for $29.6 \%$ of the soil TP (Fig. 2a), and soil aggregates of 2-8 $\mathrm{mm}$ demonstrated the second-highest TP content. The TP content of (silt+clay)-sized particles was significantly lower than that of other fractions $(P<0.05$, 


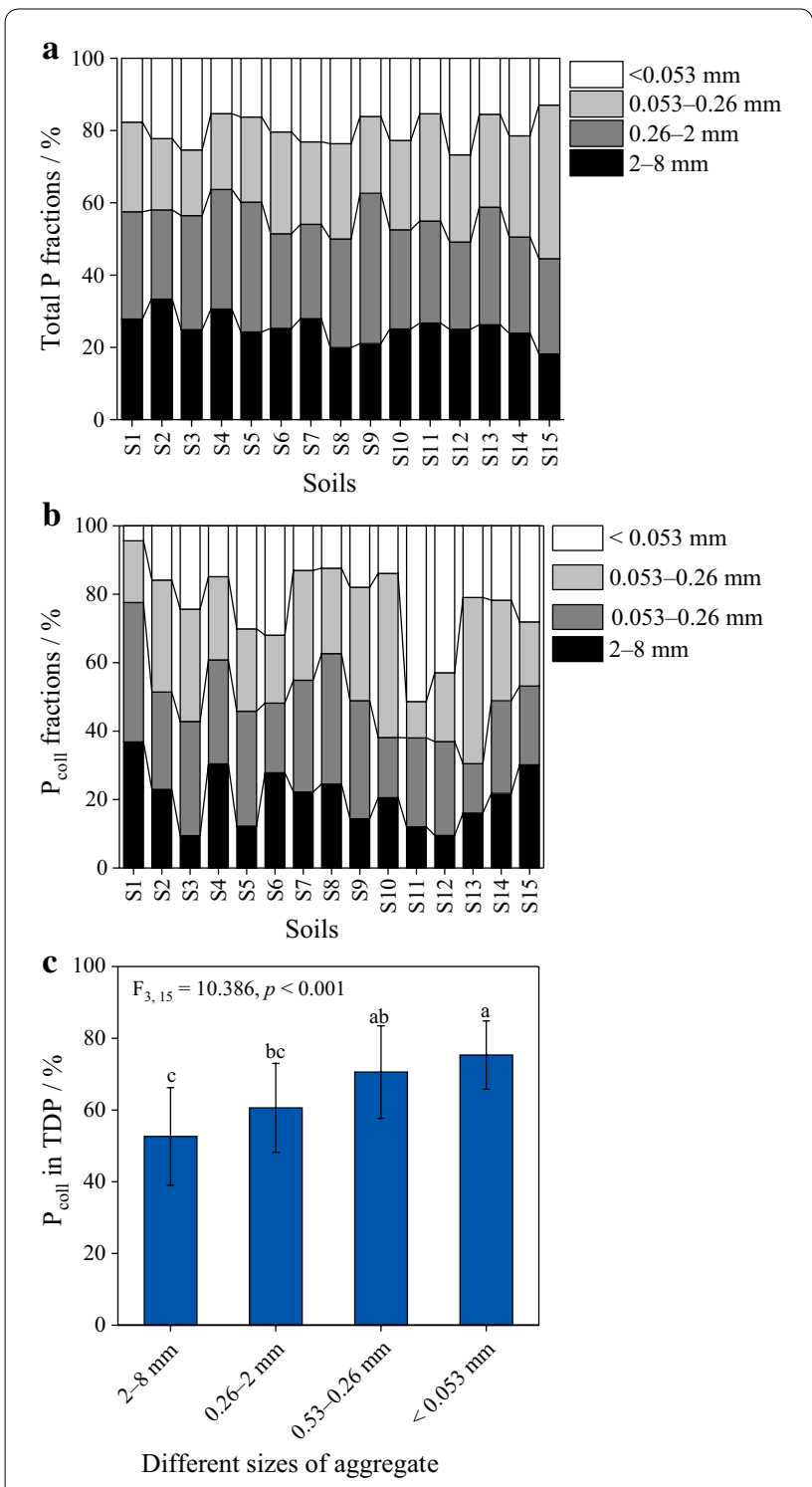

Fig. 2 Soil total $P$ fraction (a), colloidal $P\left(P_{\text {coll }}\right)$ fraction $(\mathbf{b})$ and loss potential (c) of three sized aggregates $(2-8 \mathrm{~mm}, 0.26-2 \mathrm{~mm}$, 0.053-0.26 mm) and (silt + clay) particles ( $<0.053 \mathrm{~mm})$ in 15 soils

Additional file 1: Table S1), which only accounted for $19.7 \%$ of the soil TP (Fig. 2a). Moreover, TDP, TSP, and $\mathrm{P}_{\text {coll }}$ contents were related to soil $\mathrm{pH}$, and the highest TDP content was observed in $0.26-2 \mathrm{~mm}$ aggregates in most acidic soils and in (silt + clay)-sized particles in most alkaline soils $(P<0.05$, Additional file 1: Table S1). In all soils, no significant difference was observed in the $\mathrm{P}_{\text {coll }}$ fractions between different aggregate sizes $(P>0.05$; Fig. 2b). However, the aggregate content associated with $\mathrm{P}_{\text {coll }}$ was the highest in the $0.26-2 \mathrm{~mm}$ aggregates, and the lowest in the (silt + clay)-sized particles in acidic soils; in neutral and alkaline soils, (silt + clay)-sized particles demonstrated the highest TDP and $\mathrm{P}_{\text {coll }}$ contents, followed by the $0.26-2 \mathrm{~mm}$ aggregates (Table 3 ).

\section{Loss potential of colloidal phosphorus}

After wet sieving, about $0.16-1.87 \%$ of the soil TP was lost in the supernatant as TDP, and $\mathrm{P}_{\text {coll }}$ accounted for $8.5-84.1 \%$ of the TDP (Table 2). The proportion of the easy loss $\mathrm{P}$ content in the various soils differed due to variations in soil physicochemical properties.

In general, the $\mathrm{P}_{\text {coll }}$ loss potential gradually decreased as the size of the soil aggregates increased (Fig. 2c). The $\mathrm{P}_{\text {coll }}$ loss potential was the lowest in $2-8 \mathrm{~mm}$ and $0.26-2 \mathrm{~mm}$ aggregates, with $\mathrm{P}_{\text {coll }}$ accounting for $52.6 \%$ and $60.6 \%$ of TDP, respectively. However, the $\mathrm{P}_{\text {coll }}$ loss potential of (silt + clay)-sized particles was the highest, with $\mathrm{P}_{\text {coll }}$ accounting for $75.3 \%$ of TDP (Fig. 2a). The CR value of (silt + clay)-sized particles was mostly larger than that of the other aggregate sizes, except for S7, S11 and $\mathrm{S} 15$; the CR of larger macroaggregates was lowest in most soils (Table 3).

Considering different land-use types, the $\mathrm{P}_{\text {coll }}$ content in the rice-dry land rotation and vegetable (VE) soils was significantly higher than that in paddy and orchard soils, regardless of different aggregate sizes (Fig. 3a). Higher $\mathrm{P}_{\text {coll }}$ content also was found in macroaggregates $(>0.26 \mathrm{~mm})$, except for the orchard soil (Fig. 3a). The colloidal P content in macro- and microaggregates in the paddy soils (including single cropping rice, and double-cropping rice) accounted for a relatively lower proportion of TDP $(P<0.05)$ than that in other land-use types (Fig. 3b). Overall, it accounted for only 39.3, 44.1, and $40.2 \%$ for the 2-8 $\mathrm{mm}, 0.26-2$, and $0.053-0.26 \mathrm{~mm}$ aggregates in rice fields, respectively. Colloidal P in (silt + clay)-sized particles $(<0.053 \mathrm{~mm})$ in paddy soils accounted for a TDP proportion as high as $83.0 \%$, significantly higher than that observed in the orchard and rice-dryland rotation systems (Fig. 3b). This indicated that the loss potential of $\mathrm{P}_{\text {coll }}$ was dominated by fine-grained and (silt + clay)-sized particles in paddy soils. However, the $\mathrm{P}_{\text {coll }}$ carried by all sized aggregates in dryland and rice-dryland rotation systems (orchard, rice-rape rotation, vegetable, and rice-wheat rotation) exceeded $50 \%$ of the TDP.

\section{Factors affecting colloidal $\mathrm{P}$ content and loss potential} Correlation analysis revealed no significant correlations between $\mathrm{P}_{\text {coll }}$ and $\mathrm{TC}$ or TN (Table 4). The $\mathrm{P}_{\text {coll }}$ content was significantly and positively correlated with TP in all aggregate sizes except for (silt + clay)-sized particles (Fig. 4a). Soil pH positively correlated with the aggregate-associated $\mathrm{P}_{\text {coll }}$ content, but only significantly correlated with the $\mathrm{P}_{\text {coll }}$ content of (silt + clay)sized particles $(P<0.01)$ (Fig. 4b). Additionally, $\mathrm{Al}$ and Fe significantly and positively correlated with $\mathrm{P}_{\text {coll }}$ in 
Table 2 The total dissolved P (TDP), and truly soluble P (TSP), colloidal P, colloidal P/TDP, and ratio of TDP to soil total P (TP) in the supernatant of different soils after wet sieving

\begin{tabular}{|c|c|c|c|c|c|}
\hline & $\operatorname{TDP}\left(\mathrm{mg} \mathrm{kg}^{-1}\right)$ & $\mathrm{TSP}\left(\mathrm{mg} \mathrm{kg}^{-1}\right)$ & Colloidal P $\left(\mathrm{mg} \mathrm{kg}^{-1}\right)$ & Colloidal P/TDP (\%) & TDP/TP (\%) \\
\hline S1 & $5.71 \pm 0.12$ & $2.62 \pm 0.34$ & $3.1 \pm 0.34$ & 54.17 & 0.44 \\
\hline S2 & $3.49 \pm 0.22$ & $0.79 \pm 0.18$ & $2.7 \pm 0.22$ & 77.27 & 1.75 \\
\hline S3 & $6.35 \pm 2.02$ & $1.59 \pm 0.45$ & $4.76 \pm 1.57$ & 75.00 & 1.27 \\
\hline S4 & $3.41 \pm 0.11$ & $1.83 \pm 0.11$ & $1.59 \pm 0.22$ & 46.51 & 0.43 \\
\hline S5 & $6.03 \pm 0.45$ & $2.78 \pm 0.34$ & $3.25 \pm 0.11$ & 53.95 & 0.55 \\
\hline S6 & $2.14 \pm 0.56$ & $1.43 \pm 0.67$ & $0.71 \pm 0.11$ & 33.33 & 0.71 \\
\hline S7 & $1.27 \pm 0.22$ & $0.87 \pm 0.11$ & $0.4 \pm 0.34$ & 31.25 & 0.16 \\
\hline S8 & $5.48 \pm 0.11$ & $0.87 \pm 0.11$ & $4.6 \pm 0.24$ & 84.06 & 0.78 \\
\hline S9 & $29.92 \pm 0.34$ & $27.38 \pm 0.11$ & $2.54 \pm 0.22$ & 8.49 & 1.87 \\
\hline $\mathrm{S} 10$ & $3.73 \pm 0.56$ & $0.79 \pm 0.15$ & $2.94 \pm 0.56$ & 78.72 & 0.62 \\
\hline $\mathrm{S} 11$ & $5.4 \pm 0.45$ & $2.18 \pm 0.62$ & $3.21 \pm 1.07$ & 59.56 & 1.08 \\
\hline $\mathrm{S} 12$ & $1.90 \pm 0.45$ & $1.35 \pm 0.56$ & $0.56 \pm 0.11$ & 29.17 & 0.63 \\
\hline $\mathrm{S} 13$ & $7.06 \pm 0.11$ & $4.05 \pm 0.11$ & $3.02 \pm 0.22$ & 42.70 & 0.64 \\
\hline $\mathrm{S} 14$ & $6.59 \pm 0.14$ & $4.13 \pm 0.90$ & $2.46 \pm 1.01$ & 37.35 & 0.73 \\
\hline $\mathrm{S} 15$ & $6.43 \pm 0.11$ & $2.14 \pm 1.01$ & $4.29 \pm 0.90$ & 66.67 & 0.64 \\
\hline
\end{tabular}

Data represent the average of three replicates \pm standard deviations

total sizes of soil aggregate $(P<0.05)$ (Fig. $4 \mathrm{c}, \mathrm{d})$. However, only $\mathrm{P}_{\text {coll }}$ in $2-8 \mathrm{~mm}$ aggregate significantly and positively correlated with $\mathrm{Al}$ and $\mathrm{Fe}(P<0.05)$. Moreover, $\mathrm{P}_{\text {coll }}$ was negatively correlated with $\mathrm{C} / \mathrm{P}$ (Fig. $\left.4 \mathrm{e}\right)$ and positively correlated with $\mathrm{C} / \mathrm{N}$ (Fig. 4f). The forward results of the stepwise regression demonstrated that $\mathrm{P}_{\text {coll }}$ can be described by $\mathrm{Al}, \mathrm{TP}, \mathrm{TN}$ and MWD as follows: colloidal $\mathrm{P}=-8.017+0.087 \mathrm{Al}+10.598 \mathrm{TP}-2.257 \mathrm{pH}$ -5.977MWD, $\left(R^{2}=0.605, P<0.001\right.$, Table 4$)$.

The $\mathrm{P}_{\text {coll }}$ loss potential $\left(\mathrm{P}_{\text {coll }}\right.$ in TDP) in total size of the soil aggregate negatively correlated with the $\mathrm{TC}, \mathrm{TN}$, $\mathrm{pH}, \mathrm{Ca}, \mathrm{C} / \mathrm{P}, \mathrm{C} / \mathrm{N}$ ratios of aggregates (Table $4, P<0.05$ ). Considering different sizes, $\mathrm{TC}$ and $\mathrm{TN}$ significantly and negatively correlated with $\mathrm{P}_{\text {coll }}$ loss potential in 0.26 - to 2-mm-sized aggregates. Except for (silt + clay)-sized particles, $\mathrm{P}_{\text {coll }}$ loss potential was significantly and positively correlated with $\mathrm{Al}(P<0.05) . \mathrm{P}_{\text {coll }}$ loss potential in 2 - to 8 -mm-sized aggregates was significantly and positively correlated with Fe $(P<0.05)$. However, $\mathrm{P}_{\text {coll }}$ loss potential in 0.053 - to 2 -mm-sized aggregates negatively correlated with $\mathrm{Ca}(P<0.05)$. The results of the stepwise regression demonstrated that the $\mathrm{P}_{\text {coll }}$ loss potential can be described by TC, Fe, MWD, and GMD as follows: colloidal $\mathrm{P} / \mathrm{TDP}=0.478-0.028 \mathrm{TC}+0.015 \mathrm{Fe}+0.413 \mathrm{MWD}$ $-0.363 \mathrm{GMD},\left(R^{2}=0.539, P<0.001\right.$, Table 4$)$.

\section{Discussion}

\section{Total $P$ in aggregates}

In our study, we observed that the TP content was the highest in macroaggregates of the 15 soils, while the TP content in the (silt + clay) particles was the lowest.
These results indicated that soil $\mathrm{P}$ was mainly carried by larger aggregates, which confirmed our hypothesis and were in line with those previously reported [28, 49, 50]. For examples, some scholars have observed that $\mathrm{P}$ tends to concentrate in large WSAs in longterm fertilization experiments in a reddish paddy soil [49], and others claim that aggregate-associated total organic $\mathrm{C}$, TN, and TP are preferentially enriched in large WSAs $(4.76-2.0 \mathrm{~mm})$ [50], reporting that the TP proportion increased with increasing aggregate size for native lands [35]. Higher P levels may be associated with higher levels of $\mathrm{TC}$ and $\mathrm{TN}$ in large aggregates $[50,51]$. Macroaggregates $([(\mathrm{Cl}-\mathrm{P}-\mathrm{OM}) \mathrm{x}] \mathrm{y})$ are usually formed by organic matter, clay $(\mathrm{Cl})$ and multivalent ions of $\mathrm{P}$, and other substances [52, 53]. Organic matter (and associated $\mathrm{P}$ ) is protected within stable aggregates against microbial degradation [54]. Moreover, it has been shown that the organic P forms that accumulate in soils are less available to enzymatic hydrolysis when bound to mineral surfaces $[55,56]$. On the other hand, the aggregation promoted by organic matter counteracts the dispersion of the small mineral particles (mostly Fe and Al-(hydr) oxides where $\mathrm{P}$ is retained $[57,58]$. Furthermore, this was validated by the positive correlation between aggregate-associated TP and TC, and the significant correlation between aggregate-associated TP and TN observed in this study (Additional file 1: Tables S2). 


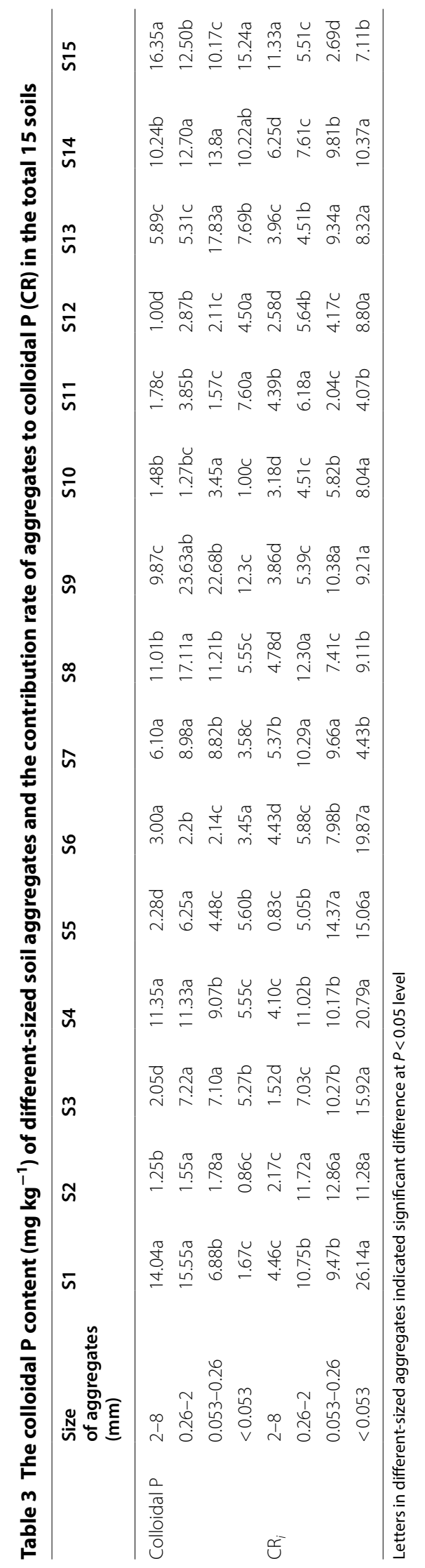



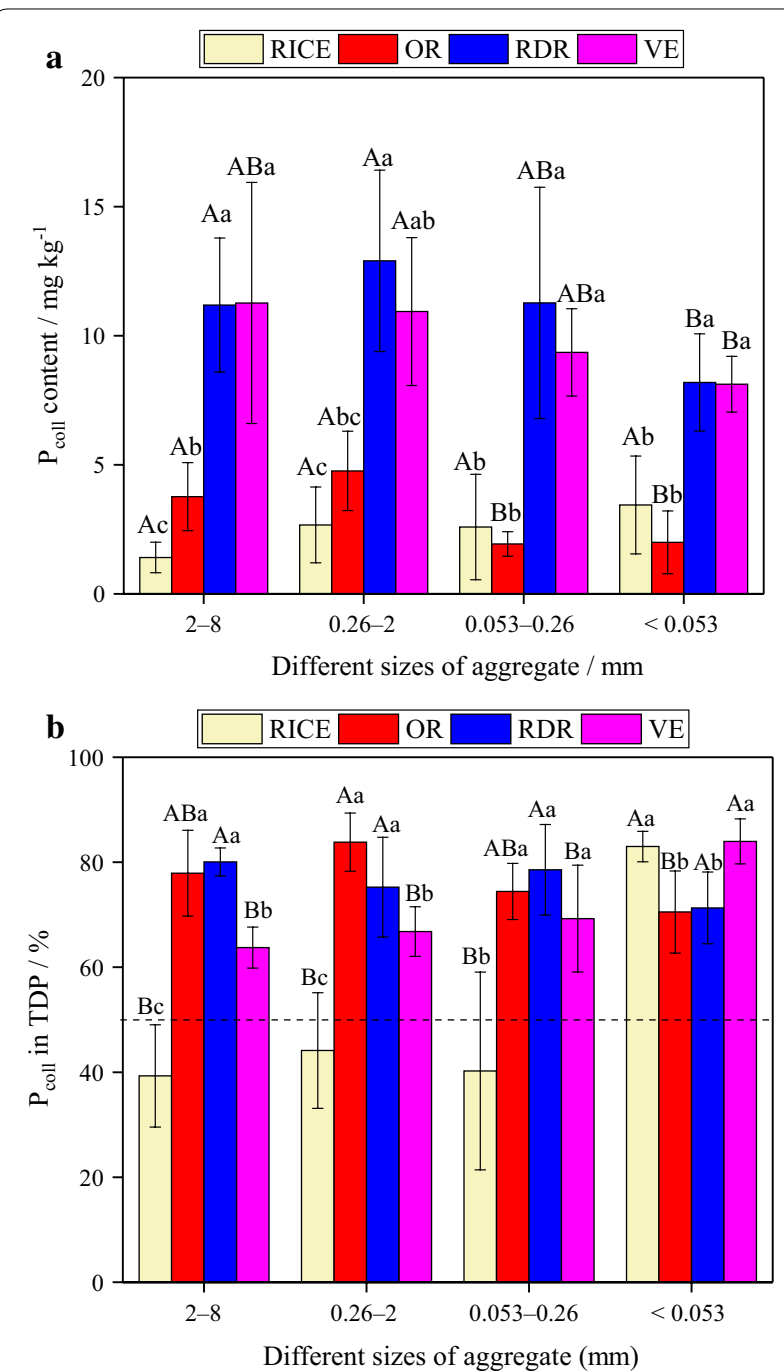

Fig. 3 Soil colloidal phosphorus content (a) and loss potential (b) of three sized aggregates ( $2-8 \mathrm{~mm}, 0.26-2 \mathrm{~mm}, 0.053-0.26 \mathrm{~mm}$ ) and (silt + clay) particles $(<0.053 \mathrm{~mm})$ under different land-use types. OR orchard soils $(n=3), R / C E$ rice fields including single- and double-cropping soils $(n=6), R D R$ rice and dryland rotation including rice-rape rotation and rice-wheat rotation soils $(n=3)$, VE vegetable soils $(n=3)$; capital letters indicated significant difference among different sizes of aggregate at $P<0.05$ level. Lowercase indicated significant difference of the same size of aggregate among land-use types at $P<0.05$ level

\section{Colloidal P content in aggregates}

In this study, although no significant difference was observed in the $\mathrm{P}_{\text {coll }}$ fractions between different aggregate sizes in all soils, we observed that TDP, TSP, and $\mathrm{P}_{\text {coll }}$ contents in soil aggregates were significantly related to soil $\mathrm{pH}$. The TDP and $\mathrm{P}_{\text {coll }}$ contents were high in macroaggregates of acidic soils, and low in microaggregates and silt+clay particles; however, contrasting results were observed in alkaline soil aggregates. This was not consistent with our hypothesis which could be attributed to soil clays being mostly negatively charged, but the aggregation of other soil colloids strongly depend on their surface charge, being favored when approaching their point of zero charge [59]. Under acidic conditions, the protonation of $\mathrm{Fe}-$, $\mathrm{Al}$-oxides, and organic matter in colloids results in positive charges, leading to their association with soil particles. However, the dissociation of Fe- and Al-hydroxyl and humic functional groups ( $\mathrm{R}-\mathrm{COOH}, \mathrm{R}-\mathrm{CH}_{2}-\mathrm{OH}, \mathrm{R}-\mathrm{OH}$ ) under alkaline conditions results in a negative charge in the colloid [59], which promotes the release of fine particulate $\mathrm{P}$ and colloidal substances, thus increasing the TDP and $\mathrm{P}_{\text {coll }}$ contents in small-sized aggregates and particles. On the other hand, the lower $\mathrm{pH}$ enhanced the adsorption of organic matter on the fine particles and masked the inorganic mineralogy, resulting in fewer chances of $\mathrm{P}$ carried by Fe- and Al-oxides [60-62]. In addition, we observed that the $\mathrm{P}_{\text {coll }}$ content in soil aggregates positively correlated with the aggregate-associated $\mathrm{Al}$ and $\mathrm{Fe}$ content. This was attributed to the greater contents of $\mathrm{Fe}$ and $\mathrm{Al}$ in acidic soil than in alkaline soil, and that the presence of $\mathrm{Al}$ and $\mathrm{Fe}$ oxides may have enhanced the adsorption of $\mathrm{P}$ and stabilization of soil aggregates [15, 31, 63]. $\mathrm{Al}$ and $\mathrm{Fe}$ oxides have been recognized as important carriers of $\mathrm{P}_{\text {coll }}$ [64-67].

\section{Loss potential of colloidal $P$ in aggregates}

We observed that the $C R$ value of (silt+clay)-sized particles was larger than that of aggregates of other sizes, while the CR of large macroaggregates was the lowest in most soils, indicating that the (silt + clay)sized particles contribute more to the $\mathrm{P}_{\text {coll }}$ loss potential, while macroaggregates immobilized soil $\mathrm{P}_{\text {coll }}$. Colloidal $\mathrm{P}$ is highly bound to $\mathrm{Fe}$ and $\mathrm{Al}$ on the surface of macroaggregates $[15,68]$, enabling the formation of a stable composite structure that can resist the shear force of pore flow $[64,65]$. Similarly, soil macroaggregates can increase the adsorption of $\mathrm{P}_{\text {coll }}$ on the surface and reduce its mobility [26]. The ratio of $P_{\text {coll }}$ to TDP reflects the release potential of $\mathrm{P}_{\text {coll }}$ in soil aggregates to soil solution. The high value indicates the high loss potential of $\mathrm{P}_{\text {coll }}$. We observed a negative correlation between the TC and TN content and $\mathrm{P}_{\text {coll }} / \mathrm{TDP}$ in aggregates, indicating that higher the TC and TN content, the less likely release of $\mathrm{P}_{\text {coll }}$ from the soil aggregates, which was further confirmed by the negative correlation between $\mathrm{TC}$ and $\mathrm{P}_{\text {coll }} / \mathrm{TDP}$ in the regression model (Table 4). Studies had shown that $\mathrm{C}$ and $\mathrm{N}$ are important carriers of $\mathrm{P}_{\text {coll }}$ (most organics act as organic colloidal complexes) $[28,69,70]$, and the organic matter could stabilize $\mathrm{Al} / \mathrm{Fe}$ colloids [71]. Therefore, increasing the carbon content in soil aggregates could 
Table 4 Results from correlation analyses and stepwise linear regressions of colloidal P and colloidal P/TDP in differentsized aggregates with soil aggregate-associated mean weight diameter (MWD), geometric mean diameter (GMD), $\mathrm{pH}$, total carbon (TC), total nitrogen (TN), C/P, C/N, Al, Fe, and Ca

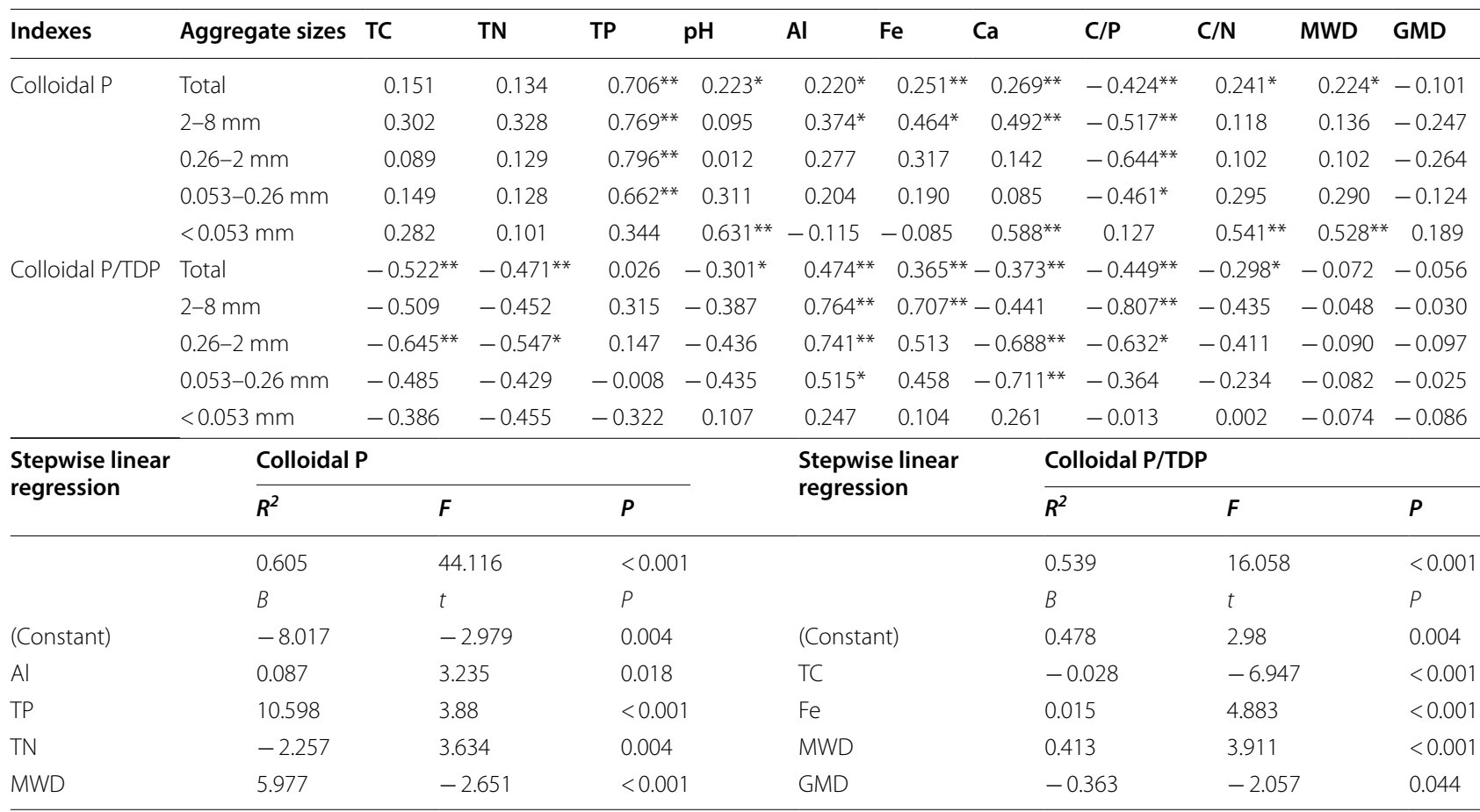

Total total soil aggregate sizes

${ }^{*} P<0.05$. ${ }^{* *} P<0.01$

be an important strategy to reduce the migration of $\mathrm{P}_{\text {coll }}$ in the soil. The ratio of $\mathrm{P}_{\text {coll }}$ to TDP for all macroaggregates in paddy soils was lower, which may be related to the long-term flooding of rice fields. Notably, the lower loss potential of $\mathrm{P}_{\text {coll }}$ in macroaggregates of paddy soils does not imply that it is less likely to be lost to water bodies. However, this could indicate that $\mathrm{P}_{\text {coll }}$ has been lost into water and discharged into the water body through the channels during rice seasons, particularly when under long-term flooding [72]. Moreover, flooding resulted in an anaerobic state in soil aggregates, and Fe bound to colloids and aggregates was reduced, resulting in excessive release and loss of $\mathrm{P}_{\text {coll }}$ [15]. We observed that aggregates of all sizes in dryland and rice-dryland rotation systems carried higher $\mathrm{P}_{\text {coll }}$ loss potential. Conversely, in paddy soils, the loss potential of $\mathrm{P}_{\text {coll }}$ in macro- and microaggregates was lower than $50 \%$ of TDP. However, $\mathrm{P}_{\text {coll }}$ in (silt + clay)-sized particles $(<0.053 \mathrm{~mm})$ in paddy soils accounted for a TDP proportion as high as $83 \%$, significantly higher than that observed in orchard and rice-dryland rotation systems. Therefore, we believe that $\mathrm{P}_{\text {coll }}$ in paddy soil is mainly carried by small silt and clay particles, which may indicate that the loss of $\mathrm{P}_{\text {coll }}$ is markedly severe in paddy soils.

\section{Conclusions}

This study discussed the relationship between $\mathrm{P}_{\text {coll }}$ and soil aggregates, providing a potential solution for soil $\mathrm{P}$ loss in agricultural systems. The soil $\mathrm{P}_{\text {coll }}$ content was affected by multiple factors including soil $\mathrm{Al}, \mathrm{Fe}$, and $\mathrm{TP}$, and the distribution of $\mathrm{P}_{\text {coll }}$ in aggregates can be regulated by altering aggregate sizes and soil $\mathrm{pH}$. As small macroaggregates contributed the most to the immobilization of $\mathrm{P}_{\text {coll }}$, it is important to increase this fraction in the soil. To this end, soil organic matter must be improved owing to its crucial role in promoting soil aggregation and reducing the risk of $\mathrm{P}_{\text {coll }}$ loss potential. Paddy soils, due to their high $\mathrm{P}_{\text {coll }} / \mathrm{TDP}$ ratio, are particularly at risk of high $\mathrm{P}_{\text {coll }}$ loss through smaller particles and worthy of further attention. 

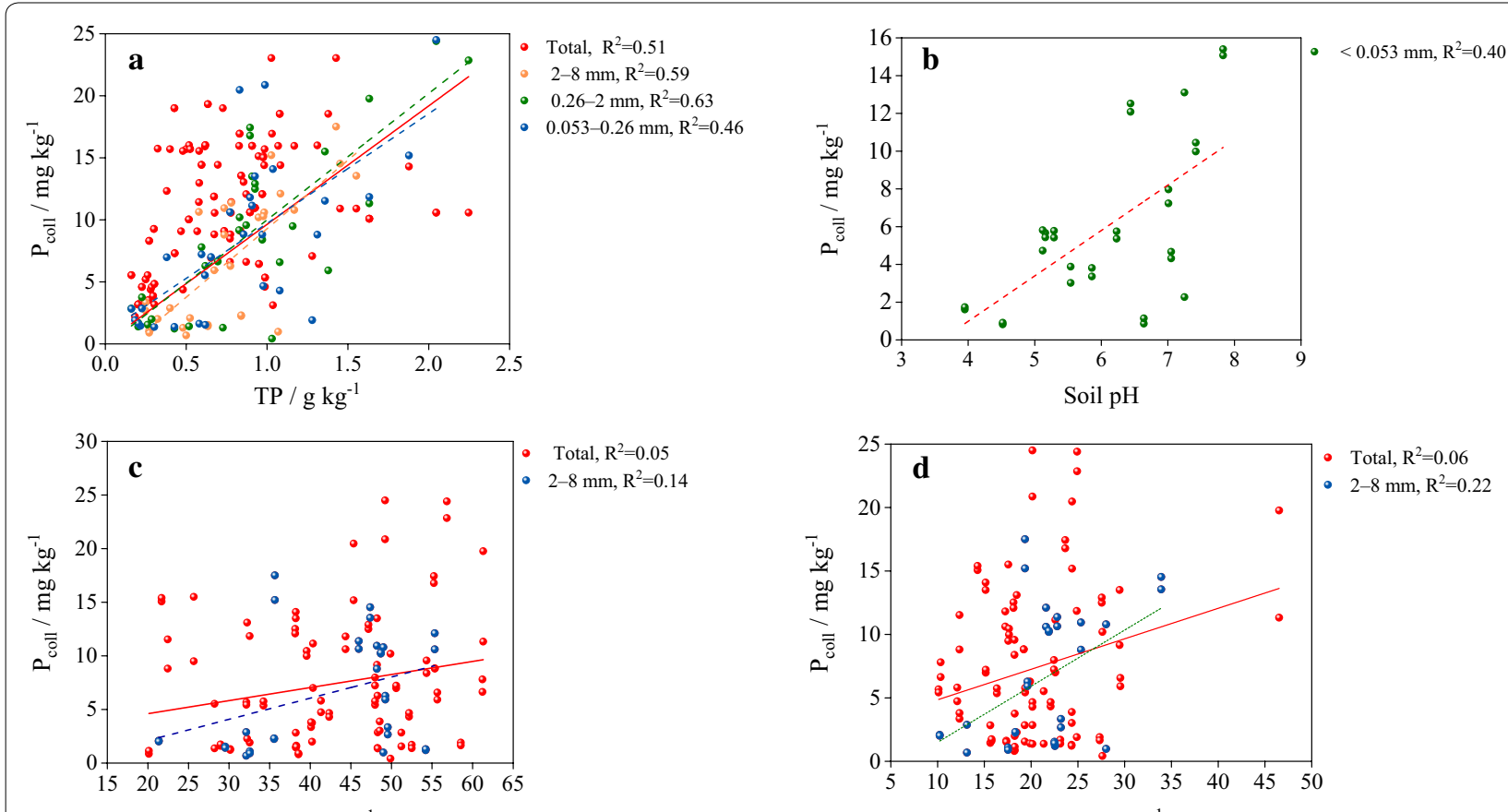

$\mathrm{Al} / \mathrm{mg} \mathrm{kg}^{-1}$
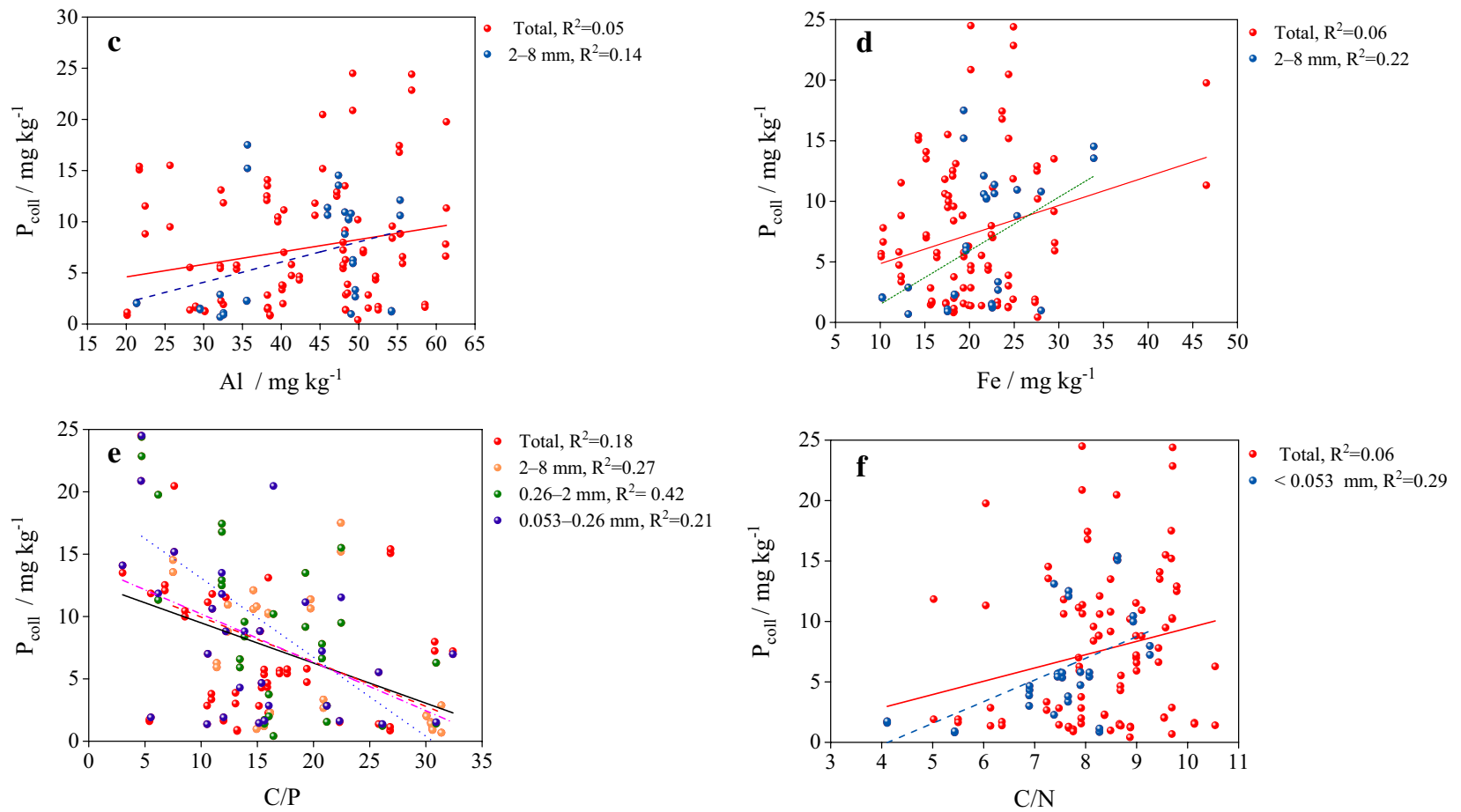

Fig. 4 Linear relationship between colloidal phosphorus ( $\left.P_{\text {coll }}\right)$ content and soil total phosphorus (TP) (a), pH (b), $\mathrm{Al}(\mathbf{c}), \mathrm{Fe}(\mathbf{d}), \mathrm{C} / \mathrm{P}(\mathbf{e})$, and C/N (f) of three sized aggregates ( $2-8 \mathrm{~mm}, 0.26-2 \mathrm{~mm}, 0.053-0.26 \mathrm{~mm}$ ) and (silt+clay) particles $(<0.053 \mathrm{~mm})$. Total=total soil aggregate sizes

\section{Supplementary information}

Supplementary information accompanies this paper at https://doi. org/10.1186/s12302-020-0299-5.

Additional file 1: Table S1. The total phosphorus (TP, $\left.\mathrm{g} \mathrm{kg}^{-1}\right)$, dissolved $\mathrm{P}\left(\mathrm{TDP}, \mathrm{mg} \mathrm{kg}^{-1}\right)$, and truly soluble $\mathrm{P}\left(\mathrm{TSP}, \mathrm{mg} \mathrm{kg}^{-1}\right.$ ) of different-sized soil aggregates in the total 15 soils. Table S2. Correlation analysis of colloidal $P$ in TP in soil aggregates and soil aggregate associated MWD, GMD, pH, $\mathrm{TC}, \mathrm{TN}, \mathrm{C} / \mathrm{N}, \mathrm{C} / \mathrm{P}, \mathrm{Al}, \mathrm{Fe}$, and $\mathrm{Ca}(n=45)$. MWD = mean weight diameter, $\mathrm{MWD}=$ mean weight diameter, $\mathrm{TC}=$ total $\mathrm{C}, \mathrm{TN}=$ total $\mathrm{N}$. Figure $\mathbf{S 1}$. Water-stable aggregate (WSA) and Dry soil aggregates (DSA) fractions of soils. Figure S2. Mean weight diameter (MWD) and geometric mean diameter (WMD) of different soil aggregates. Letters indicated significant difference among soils at $P<0.05$ level.

\section{Abbreviations}

P: Phosphorus; $\mathrm{P}_{\text {coll }}$ : Colloidal phosphorus; TP: Total phosphorus; TC: Total carbon; TN: Total nitrogen; TDP: Total dissolved P; TSP:Truly soluble P; WSA:
Water-stable aggregate; MWD: Mean weight diameter; DSA: Dry soil aggregate; GMD: Geometric mean diameter; CR: Contribution rate.

\section{Acknowledgements}

We highly appreciate the reviewers and the handling editor for their helpful comments improving the quality and clarity of this work. We are grateful for grants from National Key Research and Development Program of China (2017YFD0800103); National Natural Science Foundation of China (41671300; 41522108); National Key Science and Technology Project: Water Pollution Control and Treatment (2018ZX07208009); Natural Science Foundation of Zhejiang Province (LR16B070001).

\section{Authors' contributions}

FYL is the first author of this article; $X Q L$ is the corresponding author and designed this study; FYL, MMH, YBJ, HL and JJW completed experiment and conducted data analysis. EK and RB provided specific guidance on this research and revised this MS. All authors helped to write the manuscript. All authors read and approved the final manuscript. 


\section{Funding}

National Key Research and Development Program of China (2017YFD0800103); National Natural Science Foundation of China (41671300; 41522108); National Key Science and Technology Project: Water Pollution Control and Treatment (2018ZX07208009); Natural Science Foundation of Zhejiang Province (LR16B070001).

\section{Availability of data and materials}

The datasets used and/or analyzed during the current study are available from the corresponding author on reasonable request.

\section{Ethics approval and consent to participate}

Not applicable.

\section{Consent for publication}

Not applicable.

\section{Competing interests}

The authors declare that they have no competing interests.

\section{Author details}

${ }^{1}$ College of Environmental and Resources Sciences, Zhejiang University, Hangzhou 310058, China. ${ }^{2}$ College of Water Resources and Architectural Engineering, Tarim University, Xinjiang 843300, China. ${ }^{3}$ Institute of Environment, Resource, Soil and Fertilizer, Zhejiang Academy of Agricultural Sciences, Hangzhou 310021, China. ${ }^{4}$ Department of Life and Environmental Science, Hangzhou Normal University, Hangzhou 310036, China. ${ }^{5}$ Institute of Bioand Geosciences, Agrosphere (IBG-3), Forschungszentrum Jülich $\mathrm{GmbH}$, 52425 Jülich, Germany. ${ }^{6}$ Environment Centre Wales, Bangor University, Deiniol Road, Bangor, Gwynedd LL57 2UW, UK.

Received: 23 December 2019 Accepted: 24 January 2020

Published online: 10 February 2020

\section{References}

1. Le C, Zha Y, Li Y, Sun D, Lu H, Yin B (2010) Eutrophication of lake waters in China: cost, causes, and control. Environ Manag 45:662-668. https://doi. org/10.1007/s00267-010-9440-3

2. Yu T, Dai D, Han XJ, He CD, Fu G, Wu FC (2019) Characterization of phosphorus accumulation and release using diffusive gradients in thin films (DGT)-linking the watershed to Taihu Lake, China. Sci Total Environ 673:347-356. https://doi.org/10.1016/j.scitotenv.2019.04.102

3. Schmidt KR, Beek T, Dai XH, Dong BZ, Dopp E, Eichinger F, Hammers-Wirtz M, Haußmann R, Holbach A, Hollert H, Illgen M, Jiang X, Koehler J, Koester S, Korth A, Kueppers S, Li AL, Lohmann M, Moldaenke C, Norra S, Qin BQ, Qin YW, Reese M, Riehle E, Santiago-Schuebel B, Schaefer C, Simon A, Song YH, Staaks C, Steinhardt J, Subklew G, Tao T, Wu TF, Yin DQ, Zhao FF, Zheng BH, Zhou MY, Zou H, Zuo J, Tiehm A (2016) Since 2015 the SinoGerman research project SIGN supports water quality improvement in the Taihu region, China. Environ Sci Eur 28:24. https://doi.org/10.1186/ s12302-016-0092-7

4. Li D, Wu N, Tang S, Su G, Li X, Zhang Y, Wang G, Zhang J, Liu H, Hecker MJ, Giesy JP, Yu HX (2018) Factors associated with blooms of cyanobacteria in a large shallow lake, China. Environ Sci Eur 30:27. https://doi.org/10.1186/ s12302-018-0152-2

5. Liang $X$, Jin Y, Zhao Y, Wang Z, Yin R, Tian G (2016) Release and migration of colloidal phosphorus from a typical agricultural field under longterm phosphorus fertilization in southeastern China. J Soils Sediments 16:842-853. https://doi.org/10.1007/s11368-015-1290-4

6. Kretzschmar RBM, Grolimund D, Elimelech M (1999) Mobile subsurface colloids and their role in contaminant transport. Adv Agron 66:121-193. https://doi.org/10.1016/s0065-2113(08)60427-7

7. Norgaard T, Moldrup P, Ferre TP, Katuwal S, Olsen P, de Jonge LW (2014) Field-scale variation in colloid dispersibility and transport: multiple linear regressions to soil physico-chemical and structural properties. J Environ Qual 43:1764-1778. https://doi.org/10.2134/jeq2013.12.0510

8. Heathwaite L, Haygarth P, Matthews R, Preedy N, Butler P (2005) Evaluating colloidal phosphorus delivery to surface waters from diffuse agricultural sources. J Environ Qual 34:287-298. https://doi.org/10.2147/ OTT.S71242

9. Hens M, Merckx R (2001) Functional characterization of colloidal phosphorus species in the soil solution of sandy soils. Environ Sci Technol 35:493-500. https://doi.org/10.1021/es0013576

10. de Jonge LW, Kjærgaard C, Moldrup P (2004) Colloids and colloidfacilitated transport of contaminants in soils. Vadose Zone J 3:321-325. https://doi.org/10.2136/vzj2004.0321

11. Mayer T, Jarrell W (1995) Assessing colloidal forms of phosphorus and iron in the Tualatin River Basin. J Environ Qual 24:1117-1124. https:// doi.org/10.2134/jeq1995.00472425002400060010x

12. Shi P, Arter C, Liu X, Keller M, Schulin R (2017) Soil aggregate stability and size-selective sediment transport with surface runoff as affected by organic residue amendment. Sci Total Environ 607:95-102. https:// doi.org/10.1016/j.scitotenv.2017.07.008

13. Whalen JK, Chang C (2002) Macroaggregate characteristics in cultivated soils after 25 annual manure applications. Soil Sci Soc Am J 66:1637-1647. https://doi.org/10.1007/s10705-007-9130-6

14. Wortmann C, Shapiro C (2008) The effects of manure application on soil aggregation. Nutr Cycling Agroecosyst 80:173-180. https://doi. org/10.1007/s10705-007-9130-6

15. Henderson R, Kabengi N, Mantripragada N, Cabrera M, Hassan S, Thompson A (2012) Anoxia-induced release of colloid- and nanoparticle-bound phosphorus in grassland soils. Environ Sci Technol 46:11727-11734. https://doi.org/10.1021/es302395r

16. Bradford SA, Yates SR, Bettahar M, Simunek J (2002) Physical factors affecting the transport and fate of colloids in saturated porous media. Water Resour Res. https://doi.org/10.1029/2002WR001340

17. DeNovio NM, Saiers JE, Ryan JN (2004) Colloid movement in unsaturated porous media. Vadose Zone J 3:338-351. https://doi.org/10.2136/ vzj2004.0338

18. Lægdsmand M, de Jonge LW, Moldrup P (2005) Leaching of colloids and dissolved organic matter from columns packed with natural soil aggregates. Soil Sci 170:13-27. https://doi.org/10.2136/vzj2011.0070

19. Lægdsmand M, Moldrup P, De Jonge LW (2007) Modelling of colloid leaching from unsaturated, aggregated soil. Eur J Soil Sci 58:692-703. https://doi.org/10.1111/j.1365-2389.2006.00854.x

20. Vendelboe AL, Schjønning $P$, Moldrup $P$, Jin $Y$, Merbach I, de Jonge LW (2012) Colloid release from differently managed loess soil. Soil Sci 177:301-309. https://doi.org/10.1097/ss.0b013e3182506dd3

21. Vogel C, Mueller CW, Hoschen C, Buegger F, Heister K, Schulz S, Schloter M, Kogel-Knabner I (2014) Submicron structures provide preferential spots for carbon and nitrogen sequestration in soils. Nat Commun 5:2947. https://doi.org/10.1038/ncomms3947

22. Lekfeldt JDS, Kjaergaard C, Magid J (2017) Long-term effects of organic waste fertilizers on soil structure, tracer transport, and leaching of colloids. J Environ Qual 46:862-870. https://doi.org/10.2134/jeq20 16.11 .0457

23. Munkholm LJ, Schjønning P, Debosz K, Jensen HE, Christensen BT (2002) Aggregate strength and mechanical behaviour of a sandy loam soil under long-term fertilization treatments. Eur J Soil Sci 53:129-137. https://doi.org/10.1046/j.1365-2389.2002.00424.x

24. Ranatunga TD, Reddy SS, Taylor RW (2013) Phosphorus distribution in soil aggregate size fractions in a poultry litter applied soil and potential environmental impacts. Geoderma 192:446-452. https://doi. org/10.1016/j.geoderma.2012.08.026

25. Hao X, Chang C, Li X (2004) Long-term and residual effects of cattle manure application on distribution of $P$ in soil aggregates. Soil Sci 169:715-728. https://doi.org/10.1002/jpln.200320355

26. Garland G, Bünemann E, Oberson A, Frossard E, Snapp S, Chikowo R, Six J (2018) Phosphorus cycling within soil aggregate fractions of a highly weathered tropical soil: a conceptual model. Soil Biol Biochem 116:91-98. https://doi.org/10.1016/j.soilbio.2017.10.007

27. Udom BE, Ogunwole JO (2015) Soil organic carbon, nitrogen, and phosphorus distribution in stable aggregates of an Ultisol under contrasting land use and management history. J Plant Nutr Soil Sci 178:460-467. https://doi.org/10.1002/jpln.201400535

28. Jiang X, Bol R, Willbold S, Vereecken H, Klumpp E (2015) Speciation and distribution of $\mathrm{P}$ associated with $\mathrm{Fe}$ and $\mathrm{Al}$ oxides in aggregate-sized fraction of an arable soil. Biogeosciences 12:6443-6452. https://doi. org/10.5194/bg-12-6443-2015 
29. Cui H, Ou Y, Wang L, Wu H, Yan B, Li Y (2019) Distribution and release of phosphorus fractions associated with soil aggregate structure in restored wetlands. Chemosphere 223:319-329. https://doi. org/10.1016/j.chemosphere.2019.02.046

30. Zhang M, He Z, Calvert D, Stoffella P, Yang X, LiY (2003) Phosphorus and heavy metal attachment and release in sandy soil aggregate fractions. Soil Sci Soc Am J 67:1158-1167. https://doi.org/10.2136/sssaj2003.1158

31. Wang JG, Yang W, Yu B, Li ZX, Cai CF, Ma RM (2016) Estimating the influence of related soil properties on macro-and micro-aggregate stability in ultisols of south-central China. Catena 137:545-553. https://doi. org/10.1016/j.catena.2015.11.001

32. Rubæk GH, Guggenberger G, Zech W, Christensen BT (1999) Organic phosphorus in soil size separates characterized by phosphorus-31 nuclear magnetic resonance and resin extraction. Soil Sci Soc Am J 63:1123-1132. https://doi.org/10.2136/sssaj1999.6351123x

33. Wang $\mathrm{S}$, He X, Ye S (2020) Soil aggregation and aggregate-associated carbon, nitrogen, and phosphorus under different aged tea (Camellia sinensis L.) plantations in hilly region of southern Guangxi, China. Sci Hortic 262:109007. https://doi.org/10.1016/j.scienta.2019.109007

34. Wu W, Zheng Z, LiT, He S, Zhang X, Wang Y, Liu T (2018) Distribution of inorganic phosphorus fractions in water-stable aggregates of soil from tea plantations converted from farmland in the hilly region of western Sichuan, China. J Soil Sediment 18:906-916. https://doi.org/10.1007/ s11368-017-1834-x

35. Sheklabadi M, Mahmoudzadeh H, Mahboubi A, Gharabaghi B, Ahrens B (2014) Land use effects on phosphorus sequestration in soil aggregates in western Iran. Environ Monit Assess 186:6493-6503. https://doi. org/10.1007/s10661-014-3869-4

36. Huang R, Lan M, Liu J, Gao M (2017) Soil aggregate and organic carbon distribution at dry land soil and paddy soil: the role of different straws returning. Environ Sci Pollut Res 24:27942-27952. https://doi. org/10.1007/s11356-017-0372-9

37. Lu M, Yang M, Yang Y, Wang D, Sheng L (2019) Soil carbon and nutrient sequestration linking to soil aggregate in a temperate fen in Northeast China. Ecol Indic 98:869-878. https://doi.org/10.1016/j.ecoli nd.2018.11.054

38. Li S, Zhang S, Pu Y, LiT, Xu X, Jia Y, Deng O, Gong G (2016) Dynamics of soil labile organic carbon fractions and C-cycle enzyme activities under straw mulch in Chengdu Plain. Soil Tillage Res 155:289-297. https://doi. org/10.1016/j.still.2015.07.019

39. Wang X, Qi JY, Zhang XZ, Li SS, Virk AL, Zhao X, Xiao XP, Zhang HL (2019) Effects of tillage and residue management on soil aggregates and associated carbon storage in a double paddy cropping system. Soil Tillage Res 194:104339. https://doi.org/10.1016/j.still.2019.104339

40. Elliott ET (1986) Aggregate structure and carbon, nitrogen, and phosphorus in native and cultivated soils 1. Soil Sci Soc Am J 50:627-633. https:// doi.org/10.2136/sssaj1986.036159950050000030017x

41. Totsche KU, Amelung W, Gerzabek MH, Guggenberger G, Klumpp E, Knief C, Lehndorff E, Mikutta R, Peth S, Prechtel A (2018) Microaggregates in soils. J Plant Nutr Soil Sci 181:104-136. https://doi.org/10.1002/jpln.20160 0451

42. Sumner ME, Miller WP (1996) Cation exchange capacity and exchange coefficients. Methods Soil Anal Part 3 Chem Methods 5:1201-1229. https ://doi.org/10.1097/00010694-197006000-00009

43. Walker T, Adams A (1958) Studies on soil organic matter: I. Influence of phosphorus content of parent materials on accumulations of carbon, nitrogen, sulfur, and organic phosphorus in grassland soils. Soil Sci 85:307-318. https://doi.org/10.1097/00010694-195901000-00001

44. Ilg K, Siemens J, Kaupenjohann M (2005) Colloidal and dissolved phosphorus in sandy soils as affected by phosphorus saturation. J Environ Qual 34:926-935

45. Beauchemin S, Simard R, Cluis D (1998) Forms and concentration of phosphorus in drainage water of twenty-seven tile-drained soils. J Environ Qual 27:721-728. https://doi.org/10.2134/jeq1998.004724250027000 $30033 x$

46. Beauchemin S, Simard R, Bolinder M, Nolin M, Cluis D (2003) Prediction of phosphorus concentration in tile-drainage water from the Montreal Lowlands soils. Can J Soil Sci 83:73-87. https://doi.org/10.4141/S02-029

47. Álvaro-Fuentes J, Cantero-Martínez C, López M, Paustian K, Denef K, Stewart C, Arrúe J (2009) Soil aggregation and soil organic carbon stabilization: effects of management in semiarid Mediterranean agroecosystems. Soil Sci Soc Am J 73:1519-1529. https://doi.org/10.2136/sssaj2008.0333

48. Van Bavel C (1950) Mean weight-diameter of soil aggregates as a statistical index of aggregation 1. Soil Sci Soc Am J 14:20-23. https://doi. org/10.2136/sssaj1950.036159950014000C0005x

49. Wang W, Chen WC, Wang KR, Xie XL, Yin CM, Chen AL (2011) Effects of long-term fertilization on the distribution of carbon, nitrogen and phosphorus in water-stable aggregates in paddy soil. Agric Sci China 10:1932-1940. https://doi.org/10.1016/S1671-2927(11)60194-6

50. Adesodun J, Adeyemi E, Oyegoke C (2007) Distribution of nutrient elements within water-stable aggregates of two tropical agro-ecological soils under different land uses. Soil Tillage Res 92:190-197. https://doi. org/10.1016/j.still.2006.03.003

51. Wang S, LiT, Zheng Z (2018) Tea plantation age effects on soil aggregate-associated carbon and nitrogen in the hilly region of western Sichuan, China. Soil Tillage Res 180:91-98. https://doi.org/10.1016/j.still 2018.02.016

52. Edwards A, Bremner J (1967) Microaggregates in soils 1. J Soil Sci 18:64-73. https://doi.org/10.1111/j.1365-2389.1967.tb01488.x

53. Bronick CJ, Lal R (2005) Soil structure and management: a review. Geoderma 124:3-22. https://doi.org/10.1016/j.geoderma.2004.03.005

54. Awad YM, Lee SS, Kim K-H, OkYS, Kuzyakov Y (2018) Carbon and nitrogen mineralization and enzyme activities in soil aggregate-size classes: effects of biochar, oyster shells, and polymers. Chemosphere 198:40-48. https:// doi.org/10.1016/j.chemosphere.2018.01.034

55. Giaveno C, Celi L, Richardson AE, Simpson RJ, Barberis E (2010) Interaction of phytases with minerals and availability of substrate affect the hydrolysis of inositol phosphates. Soil Biol Biochem 42:491-498. https:// doi.org/10.1016/j.soilbio.2009.12.002

56. George TS, Simpson RJ, Gregory PJ, Richardson AE (2007) Differential interaction of Aspergillus niger and Peniophora lycii phytases with soil particles affects the hydrolysis of inositol phosphates. Soil Biol Biochem 39:793-803. https://doi.org/10.1016/j.soilbio.2006.09.029

57. Yang Y, Liu S, Wang H, Chen L, Lu L, Cai D (2019) Reduction in throughfall reduces soil aggregate stability in two subtropical plantations. Eur J Soil Sci 70:301-310. https://doi.org/10.1111/ejss.12734

58. He Y, Gu F, Xu C, Chen J (2019) Influence of iron/aluminum oxides and aggregates on plant available water with different amendments in red soils. J Soil Water Conserv 74:145-159. https://doi.org/10.2489/ jswc.74.2.145

59. Douch J, Hamdani M, Fessi H, Elaissari A (2009) Acid-base behavior of a colloidal clays fraction extracted from natural quartz sand: effect of permanent surface charge. Colloids Surf A 338:51-60. https://doi. org/10.1016/j.colsurfa.2008.12.034

60. Liang X, Liu J, Chen Y, Li H, Ye Y, Nie Z, Su M, Xu Z (2010) Effect of pH on the release of soil colloidal phosphorus. J Soil Sediment 10:1548-1556. https://doi.org/10.1007/s11368-010-0275-6

61. Kjaergaard C, Hansen HCB, Koch CB, Villholth K (2004) Properties of waterdispersible colloids from macropore deposits and bulk horizons of an Agrudalf. Soil Sci Soc Am J 68:1844-1852. https://doi.org/10.2136/sssaj 2004.1844

62. Klitzke S, Lang F, Kaupenjohann M (2008) Increasing pH releases colloidal lead in a highly contaminated forest soil. Eur J Soil Sci 59:265-273. https ://doi.org/10.1111/j.1365-2389.2007.00997.x

63. Barral M, Arias M, Guerif J (1998) Effects of iron and organic matter on the porosity and structural stability of soil aggregates. Soil Tillage Res 46:261-272. https://doi.org/10.1016/s0167-1987(98)00092-0

64. Cui Y, Xiao R, Xie Y, Zhang M (2018) Phosphorus fraction and phosphate sorption-release characteristics of the wetland sediments in the Yellow River Delta. Phys Chem Earth Parts A/B/C. 103:19-27. https://doi. org/10.1016/j.pce.2017.06.005

65. Gottselig N, Amelung W, Kirchner JW, Bol R, Eugster W, Granger SJ, Hernández-Crespo C, Herrmann F, Keizer JJ, Korkiakoski M (2017) Elemental composition of natural nanoparticles and fine colloids in European forest stream waters and their role as phosphorus carriers. Global Biogeochem Cycles 31:1592-1607. https://doi.org/10.1002/2017GB005657

66. Liu J, Yang JJ, Liang XQ, Zhao Y, Cade-Menun BJ, Hu YF (2014) Molecular speciation of phosphorus present in readily dispersible colloids from agricultural soils. Soil Sci Soc Am J 78:47-53. https://doi.org/10.2136/sssaj 2013.05.0159 
67. Petter FA, Madari BE, Silva MASd, Carneiro MAC, Carvalho MTdM, Júnior BHM, Pacheco LP (2012) Soil fertility and upland rice yield after biochar application in the Cerrado. Pesqui Agropecu Bras 47:699-706. https://doi. org/10.1590/S0100-204X2012000500010

68. van der Grift B, Osté L, Schot P, Kratz A, van Popta E, Wassen M, Griffioen J (2018) Forms of phosphorus in suspended particulate matter in agriculture-dominated lowland catchments: Iron as phosphorus carrier. Sci Total Environ 631:115-129. https://doi.org/10.1016/j.scitotenv.2018.02.266

69. Gottselig N, Nischwitz V, Meyn T, Amelung W, Bol R, Halle C, Vereecken H, Siemens J, Klumpp E (2017) Phosphorus binding to nanoparticles and colloids in forest stream waters. Vadose Zone J. https://doi.org/10.2136/ vzj2016.07.0064

70. Missong A, Bol R, Nischwitz V, Krüger J, Lang F, Siemens J, Klumpp E (2018) Phosphorus in water dispersible-colloids of forest soil profiles. Plant Soil 427:71-86. https://doi.org/10.1007/s11104-017-3430-7
71. Pokrovsky OS, Dupré B, Schott J (2005) Fe-Al-organic colloids control of trace elements in peat soil solutions: results of ultrafiltration and dialysis. Aquat Geochem 11:241-278. https://doi.org/10.1007/s10498-004-4765-2

72. Leon A, Kohyama K (2017) Estimating nitrogen and phosphorus losses from lowland paddy rice fields during cropping seasons and its application for life cycle assessment. J Cleaner Prod 164:963-979. https://doi. org/10.1016/j.jclepro.2017.06.116

\section{Publisher's Note}

Springer Nature remains neutral with regard to jurisdictional claims in published maps and institutional affiliations.

\section{Submit your manuscript to a SpringerOpen ${ }^{\circ}$ journal and benefit from:}

- Convenient online submission

- Rigorous peer review

- Open access: articles freely available online

- High visibility within the field

- Retaining the copyright to your article

Submit your next manuscript at $\boldsymbol{\nabla}$ springeropen.com 